\title{
Environmental and economic impacts of pesticide treatment in the Yam Minisett Technique
}

\author{
Stephen Morse* (i) \\ University of Surrey, Guildford, Surrey, UK \\ *Email: s.morse@surrey.ac.uk
}

(Received 01 December 2019; revised 19 August 2020; accepted 26 August 2020; first published online 13 October 2020)

\begin{abstract}
White yam (Dioscorea rotundata) is an important tuber crop in a number of countries, but especially in West Africa where it serves as a food staple as well as a cash crop as excess production is sold in local markets. But the availability of quality planting material, most notably seed yams, for yam production remains an important constraint for farmers. Techniques have been developed to help address this limitation by cutting yam tubers into pieces (minisetts), treating them with the pesticide either via a seed dressing dust or pesticide 'dips' and planting to grow seed yams of the required size and quality. But while there have been many studies on the agronomy and adoption by farmers of these techniques, there have been fewer studies on their economic performance. Indeed, to date there have been no studies that compare the economic performance of treating setts compared to leaving them untreated, and neither has there been any analysis of the environmental impact of treating setts. This paper reports the results of a study designed to address these two gaps in knowledge and is based upon results from a series of farmer-managed seed yam plots established in the middle belt of Nigeria over 4 years (2013-2016). Results suggest that revenue and gross margin were higher for treated versus untreated setts although the latter still performed relatively well. Using the Field Use Environmental Impact Quotient (EIQ), the commonly recommended pesticide sett treatments were estimated to have a low-to-moderate environmental impact, and further research is needed to see how far pesticide use can be reduced to still be effective and minimise any environmental impact.
\end{abstract}

Keywords: Yam Minisett Technique; Pesticide; Environmental impact

\section{Introduction}

White yam (Dioscorea rotundata Poir) is an important tuber crop in a number of countries, but especially in West Africa where it serves as a food staple as well as a cash crop when excess production is sold in local markets. However, given that its propagation is primarily through farmersaved vegetative material, primarily using small tubers (seed yams) usually around $250 \mathrm{~g}$ in weight (Ezeh, 1991, 1998) and cut pieces of tuber (setts) there is a danger of pest and disease continuation and build-up over successive generations. Farmers are well aware of this issue and that is why they prefer to plant good quality seed yams and setts from healthy-looking tubers, and understandably the prices paid in local markets for such material can depend on the visual quality (Ibana et al., 2012). The result is that good quality planting material can be expensive, and availability may be limited. Farmers may thus have little choice than to plant their own saved material, even if not of the best quality. Researchers have long sought ways to address these constraints on price and availability of yam planting material, and one of the methods developed in the 1970s in Nigeria is called 'Yam Minisett Technology' (YMT; Iwueke et al., 1983; Orkwor and Asadu, 1998). YMT uses 
'mother' yams of 500-1000 g that are cut to generate minisetts of between 10 and $30 \mathrm{~g}$, with a recommended weight in Nigeria of $25 \mathrm{~g}$ (Kalu et al., 1989). In theory, one 500-1000 g mother yam should yield about 20-40 minisetts of $25 \mathrm{~g}$ and as a result, YMT could increase the multiplication ratio in seed yam production from the usual value of between 1:4 and 1:8 with traditional systems to a much higher value of 1:30.

While the use of minisetts improves the multiplication ratio, there are challenges. First, cutting yam tubers into setts does expose the cut surface to drying and also to pest and disease attack once planted. Hence, the recommendation is for farmers to allow the cut surface to 'cure' (dry and harden) in a warm and humid location followed by treatment with a 'seed dressing' pesticide dust, perhaps mixed with some wood ash (Igwilo and Okoli, 1988; Kalu et al., 1989; Okoli, 1986). There are various formulations of seed dressing (e.g. Fernasan D and Aldrex T) that have been promoted and used since the 1970s for minisetts, and they typically comprise a mixture of insecticides (e.g. lindane, aldrin) and fungicides (e.g. thiram). Wood ash has also been claimed to have some additional protective effect for the cut surfaces (Kusi et al., 2013; Nwagbara et al., 2013; Otoo, 1992), although its effectiveness has been described as a variable (Onwueme and Charles, 1994). Although the treated minisetts can be directly planted into the field, the usual recommendation is for them to be pre-sprouted in a nursery before transplanting. Pre-sprouting in a medium such as sand which has been sterilised to be free of pest and disease can help minisett survival, but the process is labour intensive (Okoli, 1986). Transplanting should take place once the rains have become established at a typical depth of 9-12 cm with a plant spacing of $25 \mathrm{~cm}$ on ridges spaced at $1 \mathrm{~m}$ ( 4 stands per $\mathrm{m}^{2}=40,000$ stands/ha). Higher plant densities tend to give smaller seed yams (Osiru et al., 1987), and larger sett sizes need to be planted at larger spacings (lower densities). Farmers often 'cap' planted setts with dead leaves and straw held in place by a piece of soil so as to help reduce both soil temperature and water loss. Establishment in the field can take 4-8 weeks (Okoli, 1986), depending upon variety and minisett size, and the vines may be staked to maximise the use of incoming light or left to spread over the soil to shade out weeds.

Minisett size is an important variable in YMT as the larger the size the fewer the number of setts that can be obtained from a mother yam, but at the same time, the larger the minisett the larger the seed yam tuber that is produced. Indeed, minisett sizes greater than $25 \mathrm{~g}$ would be advantageous as they would aid survival in the field (George, 1990), but with higher sett sizes, the harvest may contain a sizeable proportion $(\sim 30 \%)$ of ware yams weighing a kilogram or more. The originally promoted $25 \mathrm{~g}$ recommendation of minisett size in Nigeria was meant to be a compromise between these competing requirements of maximising the number of setts from a single 'mother' tuber, sett survival in the field and the need for a reasonable proportion of seed yams in the harvest (Kalu et al., 1989). Hence, the YMT was promoted in Nigeria as a precise set of recommendations, almost as a 'one size fits all', and this lack of flexibility may not have helped with adoption by farmers (Morse, 2018). There have been later variants on the YMT theme and one of these is the 'Adaptive Yam Minisett Technique' (AYMT). AYMT was designed to address some of the factors that were limiting the adoption of YMT in Nigeria (Morse, 2018), primarily by doing away with the need to have a nursery and also to introduce a more effective pesticide treatment than 'seed dressing' and wood ash dusts. To address the first issue a larger sett size was introduced, thereby negating the need for a nursery, and rather than promote a single 'one size fits all' recommendation (such as $25 \mathrm{~g}$ for YMT) farmers were encouraged to experiment with their own sett size. Hence in AYMT, a range of sett sizes between 40 and $80 \mathrm{~g}$ was suggested, with farmers adapting this to suit their local conditions. Farmers can also adjust the sett size to produce a mixture of yam tuber sizes at harvest that span those best for seed yams and cutting into setts for planting as well as for consumption and sale (ware yams). Given the importance of yam for food security of many households in Nigeria, this flexibility to have a mix of seed and ware yam tubers is important. For the second issue, a pesticide 'dip' treatment was introduced whereby farmers could 'dip' their recently cut setts into a pesticide solution before curing. The use of a dip 
provides a number of advantages, including better penetration of the pesticide thereby reducing pests and diseases inside the sett rather than only on the surface.

The literature on the agronomic performance of both YMT and AYMT has grown significantly since the 1980s, and has explored the use of various sett treatments, yam, varieties and planting date to name but three. An example of agronomic studies for the AYMT can be found in Morse and McNamara (2016, 2018b). There have also been studies on the agronomic impact of using seed yams produced from AYMT on ware yam production (Morse and McNamara, 2017). However, while the agronomy of YMT and AYMT has been well-explored, there is still a relative paucity of cost-benefit analyses (CBA) of both YMT and AYMT, especially under farmermanaged conditions rather than researcher-controlled experimental plots. There have been some CBAs on seed yam production. The work of Ezeh $(1991,1998)$ at the National Root Crops Research Institute (NRCRI) in Umudike, Nigeria, provides perhaps the earliest and still most widely quoted CBA for the YMT, although the results suggested that YMT may be uneconomic with a -0.5 return on investment (gross margin:cost ratio) and a negative gross margin:revenue ratio of -1.02 . More recently, experimental plots established by Emokaro and Law-Ogbomo (2008) in Edo State, provided a favourable CBA picture across a range of sett sizes, with returns on investment ranging between 3.44 and 5.43 and efficiencies of between 0.77 and 0.84 . However, CBAs from researcher-managed plots rather than farmer-managed plots may be unrealistic in the sense that the plots often receive much more management attention and inputs than farmers would normally provide. An alternative approach is to interview seed yam growers and Oguntade et al. (2010) questioned 60 farmers in Oyo State, Nigeria, who had adopted the YMT about their inputs and yields and found a more modest value, relative to Emokaro and Law-Ogbomo (2008), return on investment of 1.24 and a gross margin:revenue of 0.55. Ibana et al. (2012) also interviewed seed yam producers and traders, this time in Edo State, and their estimates for return on investment were even lower than those of Oguntade et al. (2010) at around $0.17-0.24$, with gross margin:revenue values of 0.14-0.19. Mignouna et al. (2013) in their baseline study of seed yam growers across eight states in Nigeria arrived at a return on investment ratio of 2.31 and a gross margin:revenue of 0.7. However, the challenge with such interview-based approaches is that farmers may understate their benefits while emphasising their costs.

A third approach that rests in-between the highly-controlled experimental plots and the use of surveys is to closely monitor what farmers actually do on seed yam plots that they control. This approach takes longer as labour and other inputs have to be monitored routinely for a whole growing season and is still open to some criticism as farmers may not necessarily manage the plots as they normally would. Also, if these plots are part of a demonstration and farmer-training programme then there may still be some influence from 'outsiders' rather than farmers having complete control. An example of this 'farmer managed' approach is provided by Morse and McNamara (2018a) for two areas; Idah (Kogi State) and Amoke (Benue State) across 4 years (2013-to 2016). The plots included in this study were primarily intended as demonstrations and to provide yam farmers with a taste of the potential of AYMT for producing quality seed yams. Hence, they were not entirely farmer-managed as the intention was to train farmers in AYMT, but the bulk of the management, including timings of all activities, was entirely controlled by the farmers. As with most of the other published studies, the negative gross margins noted by Ezeh $(1991,1998)$ remain a notable exception, the findings published by Morse and McNamara (2018a) suggest that AYMT is indeed a profitable enterprise.

However, although the economic studies to date with YMT and AYMT broadly suggest that the practices are economically viable there are nonetheless challenges that remain. First, they typically do not compare the economic performance of YMT or AYMT with any of the local methods, such as 'milking', under more or less like-for-like conditions. Second, they often do not allow for benefits that might accrue in the subsequent ware yam crop using the YMT/AYMT. As the seed yams produced with YMT/AYMT can be assumed to be of better quality than the planting material that farmers typically source from their own farm, then one would expect to see agronomic and 
economic advantages in the subsequent ware yam crop. Indeed, even if the YMT/AYMT is not economically viable in itself, if it generates enough seeds of a high quality then this could generate economic benefits at the stage of ware yam production, especially as farmers may not have easy access to such high-quality planting material or they may have to incur significant transport costs in order to obtain it. The assumption here is that seed yams produced via any of the techniques is of a better quality than planting material the farmer would otherwise have access to. The agronomic benefits of using quality seed yams produced from AYMT for ware yam production have been explored by Morse and McNamara (2017) but not the economic impacts. Third, almost all of the studies to date, be they based on experiments, surveys or monitoring farmer-managed plots, have not compared the economic performance of untreated and treated setts. Such treatments are at the heart of both the YMT and AYMT, but this raises a number of concerns including availability of the pesticides of the appropriate quality and price as well as issues over farmer safety and environmental impact. Indeed, while there are published studies such as Morse and McNamara (2018b) of the agronomic impacts of using sett treatment in AYMT relative to untreated setts these have not included any CBA dimension. Finally, it has to be noted that to date there have been no published analyses of the environmental impacts of the pesticides used in YMT and AYMT. Given that the seed dressings recommended for yam have been based on 'dust' formulation of organochlorine insecticides such as aldrin and lindane as well as granular formulations of organophosphate insecticides such as carbofuran then there are clearly potential dangers to the environment to consider as well as farmer safety. It would also be interesting to see how the environmental impact of the pesticide dip used in AYMT compares to the use of pesticide dusts. Assessing the environmental impact of pesticides is not an easy task and various approaches exist including some which claim to take an 'holistic' approach by including impacts in the terrestrial and water environments and allowing for the use of various pesticides over a growing season (Levitan et al., 1995; van der Werf, 1996). Each approach is built on some simplifying assumptions and each has its own advantages and disadvantages.

It is the latter two gaps in knowledge highlighted above that provide the basis for the study reported here and the research questions are twofold:

1. What is the CBA performance of treated versus untreated setts within AYMT? Can farmers use AYMT without pesticide treatment of the setts to generate a profit?

2. What are the environmental impacts of using pesticides to treat setts in YMT and AYMT?

The research builds on previous published economic analyses of AYMT, most notably those of Morse and McNamara (2016, 2018a). However, in the latter studies, while CBAs were presented for AYMT these were not disaggregated for untreated and treated setts.

\section{Methodology}

\section{Yam plots and management}

The seed yam plots that provided the data for this research were primarily located around Idah, Kogi State and Amoke, Benue State, Nigeria, and were established in the 4 years between 2013 and 2016 (Morse and McNamara, 2018a). Both locations are in major yam-growing areas of the country. The number of plots across both locations and years included in the analysis are shown in Table 1. The farmers in Amoke did not join the project until 2014 and that explains why no data are available for them in 2013. Most of the farmers owning the plots were male and the reasons for this is that in much of Nigeria yam is considered a crop for males (Okeke et al., 2008), and men do the bulk of the physical work when it comes to land preparation, planting and staking. Women are mostly involved in marketing of the produce, but they do help with some farm activities, most notably transporting the tubers from farm to storage. However, it is 
Table 1. Number of plots established each year in Idah and Amoke

\begin{tabular}{|c|c|c|c|c|c|c|c|}
\hline \multirow[b]{2}{*}{ Year } & \multirow[b]{2}{*}{ Area } & \multirow{2}{*}{$\begin{array}{c}\text { Number of sites } \\
\text { harvested }\end{array}$} & \multicolumn{2}{|c|}{ Gender of farmer } & \multirow{2}{*}{$\begin{array}{c}\text { Plot size } \\
\left(\mathrm{m}^{2}\right)\end{array}$} & \multirow{2}{*}{$\begin{array}{l}\text { Untreated area } \\
\left(\mathrm{m}^{2}\right) \text { of plot }\end{array}$} & \multirow{2}{*}{$\begin{array}{l}\text { Treated area } \\
\left(\mathrm{m}^{2}\right) \text { of plot }\end{array}$} \\
\hline & & & Male & Female & & & \\
\hline \multirow[t]{2}{*}{2013} & Idah & 12 & 12 & 0 & 400 & 20 & 380 \\
\hline & Amoke & 0 & 0 & 0 & - & - & - \\
\hline \multirow[t]{2}{*}{2014} & Idah & 18 & 14 & 4 & 400 & 20 & 380 \\
\hline & Amoke & 12 & 6 & 6 & 400 & 20 & 380 \\
\hline \multirow[t]{2}{*}{2015} & Idah & 12 & 11 & 1 & 400 & 20 & 380 \\
\hline & Amoke & 15 & 6 & 9 & 400 & 20 & 380 \\
\hline \multirow[t]{2}{*}{2016} & Idah & 15 & 9 & 6 & 990 & 90 & 900 \\
\hline & Amoke & 37 & 23 & 14 & 600 & 0 & 600 \\
\hline Total & & 121 & 81 & 40 & & & \\
\hline
\end{tabular}

Note: Most of the plots had areas planted to untreated and treated setts. The exception to this was 2016 plots in Amoke, all of which were planted to treated setts.

not unknown for women to own yam plots and in that case, they usually pay men to do the bulk of the fieldwork.

All the plots were owned by the farmers and they were responsible for management decisions. Plot sizes varied across the years and between locations, and for the most part, each plot was planted to treated setts with a small area allocated for untreated setts. Sett sizes for both were the same, at between 40 and $80 \mathrm{~g}$. Treatment was via a pesticide dip comprising chlorpyrifos (an insecticide) and mancozeb (fungicide), and for every $10 \mathrm{l}$ of water, a total of $100 \mathrm{ml}$ of Act Force Gold (the chlorpyrifos product comprising contains $45 \%$ active ingredient) and $100 \mathrm{~g}$ of $\mathrm{Z}$-Force (the mancozeb product comprising $80 \%$ active ingredient) were added. Setts to be treated were placed into a net and lowered into the dip for a total of $10 \mathrm{~min}$ before draining of excess. Untreated and treated setts were allowed to dry for a few hours and harden in the shade before planting. The farmers did not apply the pesticide dip treatment, this was handled by specially trained extension staff, and the farmers did not pay for the pesticides or for the time of the extension staff.

Ridges were typically spaced $1 \mathrm{~m}$ apart and all setts were planted along the ridges at a spacing of $50 \mathrm{~cm}$. Plots were weeded at least twice and most farmers used staking. Farmers chose the day of planting and planted untreated and treated setts on the same day. These dates were transformed into days with 1 January each year set as day 1. Planting of yam setts for seed production typically takes place between April and the end of June and tends to happen once the farmers have planted their main 'ware' yam crop. Farmers made the decision over when to harvest, and the untreated and treatment areas were harvested at the same time.

\section{Data collection}

Agronomic and financial performance data were collected from each of the plots and for the most part, these were collected for the untreated and treated areas within each plot. Percentage sprouting was estimated between 60 and 90 days after planting. All tubers harvested from the untreated and treated areas were counted and a random sample of 50 was weighed to provide an estimate of the total weight of tubers harvested from each of the two areas. Number of tubers and weight of tubers harvested was extrapolated to per hectare.

None of the farmers involved in the research sold their produce so it was necessary to estimate revenue via a number of assumptions. Seed yams are not sold in local markets based on weight per se but are usually sold by size (small, medium, large), quality and variety in lots of 100, 400, 500, depending on locality. In more specialized markets, the above attributes are used together to display the tubers by grade. However, while whole tubers of the appropriate size are used as seed yams larger tubers may be cut into setts of roughly the same size. Thus, one large tuber may produce two or more setts that could be planted to produce ware yams. As the harvest of tubers from 
the plots varied in size, with some being too large to be used as seed yams, it was necessary to estimate the number of seed yams and setts that could be obtained from the harvested material. To assess revenue on a per hectare basis, the weight of tubers harvested from untreated and treated areas was divided by $250 \mathrm{~g}$ to produce an estimated number of planting material units comprising a combination of seed yams and setts that could be cut from larger tubers. The weight of yam planting material can vary significantly, and the figure of $250 \mathrm{~g}$ was used as it represents a typical weight for seed yams (Ezeh, 1991, 1998). The estimated number of seed yams and setts from the harvest was multiplied by a price per unit obtained from the farmers (Morse and McNamara, 2018a), and it was assumed that the price was the same for seed yams and setts and also for tubers harvested from untreated and treated plots. This assumption is open to criticism as the quality of tubers from treated setts may have been higher than from untreated setts, and thus, the price may in theory have been greater.

Assessing the costs of production for treated and untreated plots also required a number of assumptions. All of the farmers owned their land so there were no costs for land rental and none of the farmers borrowed money for seed yam production. Also, it was assumed that there were no costs incurred through depreciation of farm equipment (hoes, cutlass etc.). None of the farmers applied fertilizer. Labour records (number of people and time spent) were kept for each plot, although it was not possible to separate out the labour input for untreated and treated areas within each plot. Hence, the labour record was for the entire plot. Most of the labour input came from family members and friends rather than hiring, and to calculate the cost of labour it was necessary to impute figures based on person-hours for each activity along with the rate for paid labour in that year. The labour rates that were used are presented in Morse and McNamara (2018a). Given that the process of minisett cutting was the same for both untreated and treated areas, it was assumed that the cost of planting material once extrapolated to a per hectare basis was the same for both. Similarly, costs such as staking, vehicle hire and herbicide were assumed to be the same for both untreated and treated areas once extrapolated to a hectare. As labour costs per hectare were also assumed to be the same for untreated and treated areas then the total cost for the site was taken to be identical for the two areas once extrapolated. While this is acknowledged to be a simplifying assumption given the harvesting and transportation labour will depend to some extent on the number of weight of tubers harvested and there will be some minor costs associated with using pesticide for sett treatment, it nonetheless provides a reasonable basis.

Gross margins, taken here to be equivalent to Net Farm Income (NFI) used in some studies $(\mathrm{NFI}=$ revenue - variable costs), for untreated and treated areas were estimated by subtracting costs from revenue. A series of economic performance ratios were calculated for untreated and treated areas:

1. Revenue:cost ratio,

2. Gross margin:cost ratio (return on investment),

3. Gross margin:revenue.

These values were calculated for each of the untreated and treated plots.

\section{Analysis of agronomic and economic data}

To address the questions set within the first objective (economic performance of treated versus untreated setts within AYMT), the agronomic and economic data across the two areas (Idah and Amoke) and years (2013-2016) were combined into a single dataset. The data for untreated and treated setts were compared using the Kruskall-Wallis non-parametric test; equivalent here to a one-way ANOVA. While there are alternatives such as Welch's ANOVA, a non-parametric test was chosen as exploratory tests suggested the agronomic and economic data could not be assumed to have a normal distribution. 


\section{Environmental impact of treating setts}

The environmental impact of sett treatment in YMT and AYMT was assessed using the Environmental Impact Quotient (EIQ) of Kovach et al. (1992) of the New York State Integrated Pest Management programme. EIQ is by no means the only approach that could have been taken but it is one that has existed for some decades and does claim to take a holistic approach to the environmental impacts of pesticides (Levitan et al., 1995; van der Werf, 1996). EIQ assesses the environmental impact of pesticides using data held for each pesticide within the EXTOXNET database (available at extoxnet.orst.edu/), and an online EIQ calculator is available (Grant, undated). The variables used in the calculation of the EIQ are as follows:

1. $\mathrm{DT}=$ Acute dermal toxicity,

2. $\mathrm{D}=$ Toxicity to birds,

3. $\mathrm{F}=$ Toxicity to fish,

4. $\mathrm{Z}=$ Toxicity to bees,

5. $\mathrm{L}=$ Leaching potential,

6. $\mathrm{R}=$ Runoff potential,

7. $\mathrm{S}=$ Soil residue half-life,

8. $\mathrm{SY}=$ Mode of action,

9. $\mathrm{C}=$ Chronic health effects,

10. $\mathrm{P}=$ Plant surface health effects,

11. $\mathrm{B}=$ Toxicity to beneficial organisms.

These variables are used to find three components of impact which Kovach et al. (1992) refers to as 'farm worker', 'consumer' and 'ecological', and these three components are averaged to produce the EIQ. The 'farm worker' component is calculated as:

$$
\text { Farmworker }=\mathrm{C}\left(\mathrm{DT}^{*} 5\right)+\mathrm{C}\left(\mathrm{DT}^{*} \mathrm{P}\right) .
$$

The $\mathrm{C}\left(\mathrm{DT}^{\star} 5\right)$ component covers the impact of the pesticide on the applicator while the $\mathrm{C}\left(\mathrm{DT}^{\star} \mathrm{P}\right)$ covers the exposure during 'picking' (harvesting).

Impact on consumers is calculated as:

$$
\text { Consumer } \left.=\mathrm{C}^{*}((\mathrm{~S}+\mathrm{P}) / 2)^{*} \mathrm{SY}\right)+\mathrm{L} \text {. }
$$

Here, the $\left.C^{\star}((S+P) / 2) * S Y\right)$ covers the impact of the pesticide on consumers while $L$ is the impact from leaching of the pesticide into the water which, in turn, could have an impact on wider society via the water supply.

The ecological component is the more complex of the three as it has a number of subcomponents covering the aquatic and terrestrial environments:

$$
\begin{gathered}
\text { Fish }=\mathrm{F}^{*} \mathrm{R}, \\
\text { Birds }=\mathrm{D}^{*}\left((\mathrm{~S}+\mathrm{P}) / 2^{*} 3,\right. \\
\text { Bees }=\mathrm{Z}^{*} \mathrm{P}^{*} 3, \\
\text { Beneficialorganisms }=\mathrm{B}^{*} \mathrm{P}^{*} 5 .
\end{gathered}
$$

The 'ecological' component is found by adding the following four toxicities:

$$
\text { Ecological }=\text { Fish }+ \text { Bird }+ \text { Bee }+ \text { Beneficial. }
$$

In order to allow for the fact that there are various formulations for the same pesticide and application rates may vary depending on the context, the EIQ is multiplied by the quantity of pesticide active ingredient that has been applied to generate what Kovach et al. (1992) calls the EIQ 'Field Use Rating': 
Field Use EIQ = EIQ x Active Ingredient in product (\%) $\mathrm{x}$ Rate of application of product $(\mathrm{kg} / \mathrm{ha})$.

Higher values of Field Use EIQ equate to greater environmental impact, and Kovach et al. (1992) suggest the following 'categories' of pesticide impact based upon the Field Use EIQ:

1. $<25$ very low impact,

2. $<50$ low impact,

3. 50-100 moderate impact,

4. $>100$ high impact,

5. $>150$ very high impact.

While the EIQ attempts to capture the breadth of pesticide impact in the field, it nonetheless comprises many assumptions, all of which can be questioned. These are not covered here and for a fuller description of the assumptions behind the EIQ the reader is referred to the paper by Kovach et al. (1992) and the report of Eshenaur et al. (undated) available online. The assumptions can be critiqued of course, including the choice of variables that comprise the EIQ as well as their relative weightings. Nonetheless, the EIQ has been shown to be an easily applied and helpful tool for assessing the environmental impact of pesticides, and the results compare well with other environmental impact indices (Muhammetoglu et al., 2010). In this paper, no adjustments have been made to the methodology and assumptions of the EIQ, although the context of using yam sett treatments in Nigeria does arguably provide some basis for a modified approach. For example, the sett treatments are provided either via a dust (YMT) or dip (AYMT) rather than being sprayed, and the tropical environment, with heavy rains during the growing season of yam, would also suggest a different approach with regard to leaching. Thus, it is fully acknowledged that the EIQ approach does have its limitations and can only hope to provide an approximation of impact.

\section{Results}

Table 2 presents the mean values, standard errors and sample sizes of agronomic and economic variables for the combined dataset (i.e. plots established in Idah and Amoke between 2013 and 2016). Sett treatment had a positive impact on germination rate, average tuber weight, number of tubers harvested and yield; findings that have already been well-noted in the literature (Morse and McNamara, 2018a, 2018b). For the economic variables, sett treatment had no significant impacts on total costs of production but did increase revenue and gross margin. It should be noted here that the estimation of revenue was based on a number of assumptions to transform weight of harvest to number of seed yams and setts and subsequently to a financial value, and no account was taken of tuber quality. But even with these simplifications, the use of untreated setts still generated an average gross margin of $\mathrm{N} \mathrm{3,062,157}(\mathrm{SE}=312,801)$ per hectare.

In order to more readily place the results from the AYMT plots in Idah and Amoke into context, Table 3 presents values for three economic performance indicators and compares them for untreated and treated plots. In each case, the indicator was higher for plots planted to treated setts compared to untreated. These results can be compared with the same indicators employed in a number of other seed yam studies summarised in Table 4 . These studies span something of a spectrum from, at one end of the scale, controlled experiments (Emokaro and Law-Ogbomo, 2008; Ezeh, 1991) to at the other end of the scale interviews with growers and marketers (Ibana et al., 2012; Oguntade et al., 2010). The AYMT research presented here has values for the three performance ratios of untreated plots that compare well with those in Table 4 .

The Field Use EIQ results for the AYMT and some of the 'traditional' YMT dust treatments are shown in Table 5. Also shown are the Field Use EIQ values for the treatments employed in the Emokaro and Law-Ogbomo (2008) experiments that arguably could represent an extreme given that they did use a lot of pesticide, especially carbofuran granules. The Field Use EIQs for the 
Table 2. Results of a Kruskal-Wallis test comparing agronomic and economic variables for untreated and treated plots

\begin{tabular}{|c|c|c|c|c|}
\hline \multirow[b]{2}{*}{ Variable } & \multirow[b]{2}{*}{ Statistic } & \multicolumn{2}{|c|}{ Treatment } & \multirow{2}{*}{$\frac{\text { Kruskall-Wallis }}{\text { (adjusted for ties) }}$} \\
\hline & & Untreated & Treated & \\
\hline \multirow[t]{3}{*}{ Germination rate (\%) } & Mean (SE) & $71.41(2.22)$ & $83.53(1.57)$ & \\
\hline & Median & 74.4 & 88.5 & $22.69^{\star \star \star}$ \\
\hline & $\mathrm{N}$ & 84 & 121 & \\
\hline \multirow[t]{3}{*}{ Average tuber weight $(\mathrm{kg})$} & Mean (SE) & $0.413(0.03)$ & $0.738(0.025)$ & \\
\hline & Median & 0.3675 & 0.76 & $61.67^{\star \star \star}$ \\
\hline & $\mathrm{N}$ & 84 & 121 & \\
\hline \multirow[t]{3}{*}{ Number of tubers/ha } & Mean (SE) & $15,804(831)$ & $17,851(534)$ & \\
\hline & Median & 15,000 & 17.237 & $7.55^{\star \star}$ \\
\hline & $\mathrm{N}$ & 84 & 121 & \\
\hline \multirow[t]{3}{*}{ Tuber weight (kg/ha) } & Mean (SE) & $6,790(636)$ & $13,449(609)$ & \\
\hline & Median & 5,230 & 12,747 & $51.65^{\star \star \star}$ \\
\hline & $\mathrm{N}$ & 84 & 121 & \\
\hline \multirow[t]{3}{*}{ Total cost (Naira/ha) } & Mean (SE) & $887,417(29,183)$ & $907,417(29,183)$ & \\
\hline & Median & 888,125 & 908,125 & $0.37^{\mathrm{ns}}$ \\
\hline & $\mathrm{N}$ & 121 & 121 & \\
\hline \multirow[t]{3}{*}{ Revenue (Naira/ha) } & Mean (SE) & $3,844,004(324,052)$ & $9,352,536(393,310)$ & \\
\hline & Median & $2,814,480$ & $8,928,979$ & $74.61^{\star \star \star}$ \\
\hline & $\mathrm{N}$ & 84 & 121 & \\
\hline \multirow[t]{3}{*}{ Gross margin (N/ha) } & Mean (SE) & $3,062,157(312,801)$ & $8,445,119(382,790)$ & \\
\hline & Median & $2,036,910$ & $7,961,389$ & $75.77^{\star \star \star}$ \\
\hline & $\mathrm{N}$ & 84 & 121 & \\
\hline
\end{tabular}

$\mathrm{SE}=$ standard error; ns $=$ not significant at $p<0.05 ;{ }^{*} p<0.05 ;{ }^{* \star} p<0.01 ;{ }^{\star \star \star} p<0.001$.

Table 3. Results of a Kruskal-Wallis test comparing some economic performance indicators for untreated and treated plots

\begin{tabular}{|c|c|c|c|c|}
\hline \multirow[b]{2}{*}{ Indicator } & \multirow[b]{2}{*}{ Statistic } & \multicolumn{2}{|c|}{ Treatment } & \multirow{2}{*}{$\frac{\text { Kruskall-Wallis }}{\text { (adjusted for ties) }}$} \\
\hline & & Untreated & Treated & \\
\hline \multirow[t]{3}{*}{ Ratio of revenue to total cost } & Mean (SE) & $5.124(0.391)$ & $10.793(0.464)$ & \\
\hline & Median & 4.238 & 10.576 & $63.36^{\star \star \star}$ \\
\hline & $\mathrm{N}$ & 84 & 121 & \\
\hline \multirow[t]{3}{*}{ Ratio of gross margin to total cost } & Mean (SE) & $4.124(0.391)$ & $9.793(0.464)$ & \\
\hline & Median & 3.238 & 9.576 & $63.36^{\star \star \star}$ \\
\hline & $\mathrm{N}$ & 84 & 121 & \\
\hline \multirow[t]{3}{*}{ Ratio of gross margin to revenue } & Mean (SE) & $0.6495(0.0364)$ & $0.7778(0.0912)$ & \\
\hline & Median & 0.7631 & 0.9054 & $63.36^{\star \star \star}$ \\
\hline & $\mathrm{N}$ & 84 & 121 & \\
\hline
\end{tabular}

$\mathrm{SE}=$ standard error; ns $=$ not significant at $p<0.05 ;{ }^{*} p<0.05 ;{ }^{* \star} p<0.01 ;{ }^{\star \star \star} p<0.001$.

Emokaro and Law-Ogbomo (2008) experiments are classified as 'very high' (188.9) and this is perhaps not too surprising given their use of carbofuran granules applied to each stand. This does represent an unusual context, it was an experiment after all, and there are no recommendations that are routinely passed to farmers suggesting that they use carbofuran for seed yam production. For the two seed dressing treatments (Fernasan D and Aldrex T; 43.5 and 97.1, respectively) along with the 'dip' treatment used in AYMT (72.8), the Field Use EIQs are classified as low to moderate.

\section{Discussion}

This study is the first of its type to explore the economic and environmental impacts of treating yam setts with pesticide compared to not treating them. The positive impact of treatment on 
Table 4. Summary of some economic performance ratios for seed yam production in Nigeria

\begin{tabular}{|c|c|c|c|c|c|c|c|c|}
\hline Study & Place & Sample size & $\begin{array}{l}\text { Sett size } \\
\text { (g) }\end{array}$ & $\begin{array}{l}\text { Yam } \\
\text { variety }\end{array}$ & Treated & $\begin{array}{c}\text { Revenue: } \\
\text { cost }\end{array}$ & $\begin{array}{l}\text { Gross } \\
\text { margin: } \\
\text { cost }\end{array}$ & $\begin{array}{l}\text { Gross } \\
\text { margin: } \\
\text { revenue }\end{array}$ \\
\hline $\begin{array}{l}\text { Ezeh } \\
\qquad(1991)\end{array}$ & NRCRI, Umudike & Not provided & 25 & Obioturugo & $\begin{array}{c}\text { Pesticide } \\
\text { dust }\end{array}$ & 0.50 & -0.50 & -1.02 \\
\hline $\begin{array}{l}\text { Oguntade } \\
\text { et al. } \\
\text { (2010) }\end{array}$ & Oyo State & $\begin{array}{l}\text { Survey of } 60 \\
\text { farms (1 year) }\end{array}$ & $\begin{array}{l}\text { Not } \\
\text { reported }\end{array}$ & $\begin{array}{l}\text { Not } \\
\text { reported }\end{array}$ & $\begin{array}{l}\text { Not } \\
\text { reported }\end{array}$ & 2.24 & 1.24 & 0.55 \\
\hline \multirow{3}{*}{$\begin{array}{l}\text { Ibana et al. } \\
\qquad(2012)\end{array}$} & \multirow{3}{*}{$\begin{array}{l}\text { Illushi hinterland, } \\
\text { Edo State }\end{array}$} & \multirow{3}{*}{$\begin{array}{l}\text { Survey of } 108 \\
\text { households } \\
\text { and } 16 \\
\text { traders }\end{array}$} & \multirow[t]{3}{*}{$120-150$} & \multirow{3}{*}{$\begin{array}{l}\text { Alumaco } \\
\text { Ekpe } \\
\text { Obitulogo }\end{array}$} & \multirow{3}{*}{$\begin{array}{l}\text { Not } \\
\text { reported/ } \\
\text { could be } \\
\text { either }\end{array}$} & 1.24 & 0.24 & 0.19 \\
\hline & & & & & & 1.19 & 0.19 & 0.16 \\
\hline & & & & & & 1.17 & 0.17 & 0.14 \\
\hline $\begin{array}{l}\text { Mignouna } \\
\text { et al. } \\
\text { (2013) }\end{array}$ & $\begin{array}{l}\text { Niger, Nasarawa, } \\
\text { Benue, Ebonyi, } \\
\text { Enugu, Kogi, Edo } \\
\text { and Oyo }\end{array}$ & $\begin{array}{l}\text { Baseline } \\
\text { study }\end{array}$ & $20-25$ & $\begin{array}{l}\text { Not } \\
\text { reported }\end{array}$ & $\begin{array}{l}\text { Not } \\
\text { reported/ } \\
\text { could be } \\
\text { either }\end{array}$ & 3.31 & 2.31 & 0.70 \\
\hline \multirow{12}{*}{$\begin{array}{l}\text { Emokaro } \\
\text { and } \\
\text { Law- } \\
\text { Ogbomo } \\
(2008)\end{array}$} & \multirow{6}{*}{$\begin{array}{l}\text { Evboneka (Forest } \\
\text { zone; Edo State) }\end{array}$} & \multirow{6}{*}{$\begin{array}{l}\text { One site } \\
\text { (experiment } \\
\text { with four } \\
\text { reps) }\end{array}$} & 25 & Not & \multirow{6}{*}{$\begin{array}{l}\text { Pesticide } \\
\text { dip and } \\
\text { Carbofuran }\end{array}$} & 4.44 & 3.44 & 0.77 \\
\hline & & & 30 & reported & & 4.97 & 3.97 & 0.80 \\
\hline & & & 35 & & & 5.01 & 3.98 & 0.80 \\
\hline & & & 40 & & & 5.2 & 4.2 & 0.81 \\
\hline & & & 45 & & & 4.92 & 3.92 & 0.80 \\
\hline & & & 50 & & & 5.33 & 4.19 & 0.81 \\
\hline & \multirow{6}{*}{$\begin{array}{l}\text { Irrua (Forest- } \\
\text { Savanna transition } \\
\text { zone; Edo State) }\end{array}$} & \multirow{6}{*}{$\begin{array}{l}\text { One site } \\
\text { (experiment } \\
\text { with four } \\
\text { reps) }\end{array}$} & 25 & Not & \multirow{5}{*}{$\begin{array}{l}\text { Pesticide } \\
\text { dip and } \\
\text { Carbofuran }\end{array}$} & 5.53 & 4.53 & 0.82 \\
\hline & & & 30 & reported & & 6.43 & 5.43 & 0.84 \\
\hline & & & 35 & & & 6.33 & 5.34 & 0.84 \\
\hline & & & 40 & & & 5.95 & 5.08 & 0.83 \\
\hline & & & 45 & & & 5.68 & 4.68 & 0.82 \\
\hline & & & 50 & & & 5.42 & 4.29 & 0.82 \\
\hline
\end{tabular}

agronomic variables such as germination rate, average tuber weight, number and weight of tubers harvested has been well-reported in the literature, including for the pesticide dip within AYMT relative to the use of untreated setts, and the findings do not require any further elaboration here (Morse and McNamara, 2018a, 2018b, in press). While it was necessary to make a number of assumptions to monetise the yields and estimate costs, the results clearly suggest that the agronomic benefits are translated into economic ones, with an increase in revenue from planting

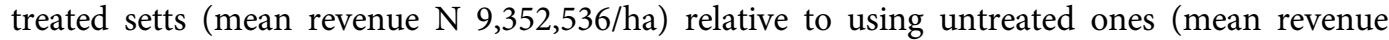

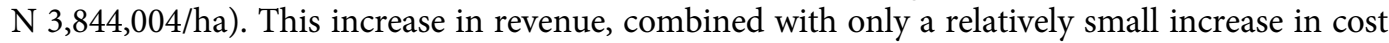
for using treated setts, results in a significantly higher average gross margin (revenue-costs) for treated setts ( $8,445,119 /$ ha) compared to untreated (N 3,062,157/ha). Nonetheless, the important point here is that while the use of sett treatments provided significant agronomic and economic benefits even the use of non-treated setts still generated a significant profit.

Estimating costs of production for resource-poor farmers is a challenge and does require assumptions such as those set out in the methodology section. Across all of the plots employed in the research described here, the major costs in production were found to be labour (mean 62.5\%; standard deviation 15.6\%) and planting material (mean 32\%; standard deviation $14.2 \%)$. Other costs, covering staking materials, herbicide, vehicle hire for transporting the yams after harvest and the pesticides used for sett treatment were a relatively small percentage of the total (mean 5.4\%; standard deviation 4.9\%). The relatively high standard deviation compared to the mean reflects the fact that these minor costs could vary significantly between farmers. For example, some would use herbicide and hire transport from the farm while others would not. The cost of sett treatment was more standardised across farmers as the pesticides were supplied to them and the treatment was undertaken by extension staff. Over the period of the research (2013-2016), the two pesticides used for sett treatment cost between N2,000 and N4,000 for 


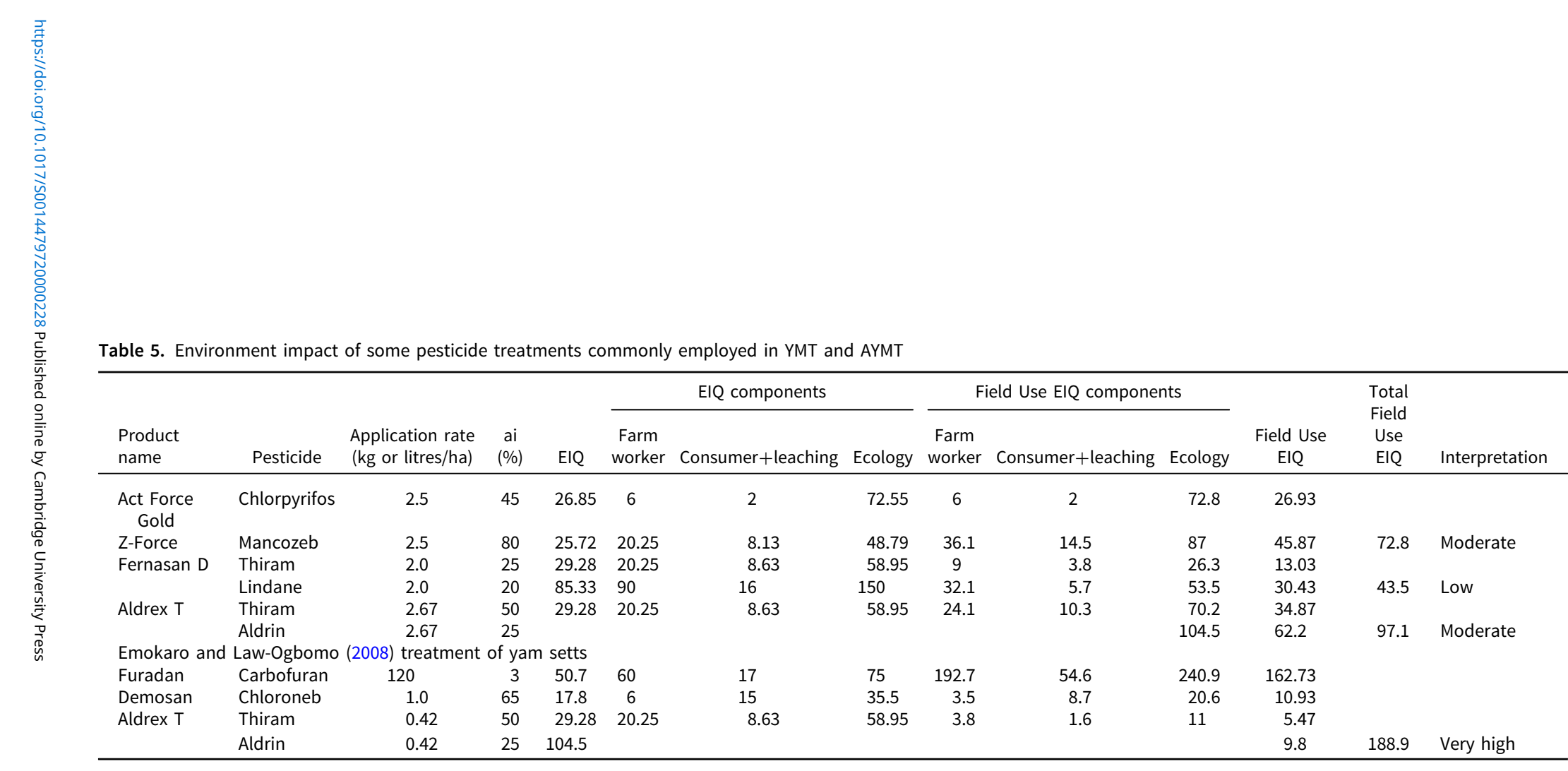

Note: Values in the table for Environmental Impact Quotient (EIQ) components are based on data held for each pesticide within the EXTOXNET database. 
11 (Act Force Gold) and $1 \mathrm{~kg}$ (Z-Force). At application rates of approximately $2.5 \mathrm{~kg}$ or litres per hectare, and assuming the larger cost of N4,000, this equates to approximately $2.5 \%$ of the average cost of production. This pattern of costs broadly matches other studies for yam production, and some recent examples can be found in Akinola et al. (2019), Mbah (2019) and Oduntan (2019).

However, there are some important caveats to note here beyond those already noted regarding the estimation of revenue and costs. First, the conclusions above are based on pooled data across two different locations (Idah and Amoke) and over 4 years (2013-2016). The averages in Tables 2 and 3 do have a degree of associated variation and the analysis does not take into account any interactions between these locations and over the 4 years. Indeed, it is likely that the economic benefits of using sett treatment will vary over space and time, perhaps reflecting local market conditions. Second, the use of a pesticide dip does require farmers to spend time sourcing pesticide of the required quality which can itself be a significant challenge in Nigeria (Oruonye and Okrikata, 2010).

In terms of the three economic performance ratios (Table 3), sett treatment improved all three of them compared to using untreated setts. Nonetheless, for untreated plots, the values reported in this paper compare well with those of a variety of studies summarised in Table 4 such as the work reported by Mignouna et al. (2013) in their baseline study of seed yam producers in Niger, Nasarawa, Benue, Ebonyi, Enugu, Kogi, Edo and Oyo States. While Mignouna et al. (2013) do not record whether their sampled farmers have used pesticides, it is likely that their ratios are based on a combination of using untreated and treated planting material. Indeed, the untreated plot ratios in Table 3 even compare well with those of Emokaro and Law-Ogbomo (2008) in the context of a controlled experiment with a relatively high level of input use including fertilizer. The ratio values are better than those reported by Oguntade et al. (2010) for seed yam producers in Oyo State and Ibana et al. (2012) for seed yam growers in Edo State. One of the potential problems with survey-based studies is that farmers may over-emphasise their costs and underplay their revenues and gross margins may be lower as a result. Hence, the two extremes of research-managed experimental plots and interview-based surveys in Table 4 probably span the range one would expect to gather from research, and studies such as this one that closely monitor farmer expenditure and activities would arguably have the best likelihood of getting figures that match reality even though a number of assumptions had to be made. Even so, average gross margin:revenue values of $65 \%$ (untreated setts) to $78 \%$ (treated setts) for a seed yam enterprise would seem reasonable. The interesting point here is that even without any treatment of the setts the economic returns were still positive and given that farmers can find it challenging to source pesticides of the correct quality (Oruonye and Okrikata, 2010) and at a price that they can afford then this is important. The larger sett size of AYMT relative to YMT no doubt makes a difference regarding survival, especially if the 'mother' tubers are carefully selected to avoid using material that is infected with pests and diseases, but it does mean that more 'mother' yams have to be used. Nonetheless, the use of a dip-based sett treatment does help prevent re-infestation of the material from nematodes and fungal pathogens, and this is an important issue in yam production.

A limiting factor for potential seed yam growers is the supply of funding for investment in such enterprises, although none of the farmers included in this study sourced credit for growing the seed yams. Credit for agriculture is available in Nigeria via the commercial and cooperative banks, and the effective interest rate is typically less than $10 \%$ via the Agricultural Credit Support Scheme (ACSS) and the Commercial Agriculture Credit Scheme (CACS). However, there are still significant risks both for the lender and grower (Fadeyi, 2018) and the update of such credit tends to be low (Badiru, 2010). Some of the plots in Idah and Amoke were lost due to a number of factors including flooding and damage by migratory herdsmen (Fulani), and although these are not large in number there is still a perceived risk and it is perhaps understandable that farmers may be reluctant to invest in such an expensive enterprise as seed yam even if the potential returns are good. 
The environmental impacts, assessed via the EIQ approach, of the sett treatments used in seed yam production (either via seed dressing dusts or dip) are broadly low to moderate. The exception is the treatments used by Emokaro and Law-Ogbomo (2008) which involved the use of carbofuran granules applied to each stand as well as a sett treatment, but these were experimental plots and there have been no recommendations to farmers that they should use the same approach. In the case of the seed dressing dusts recommended as part of YMT the bulk of the Field Use EIQ comes from the insecticide components (lindane and aldrin, respectively for Fernasan D and Aldrin T), both of which are organochlorine and have a degree of longevity in the environment which is desirable in an agronomic sense but negative in terms of environmental impact. In the case of the pesticide dip employed in AYMT the biggest contributor to the Field Use EIQ is from mancozeb, a fungicide. Indeed, it may be possible to use other fungicides that have less environmental impact in the AYMT pesticide dip or perhaps a formulation that is less than the $80 \%$ wettable powder that is currently recommended. Indeed, one of the advantages of using pesticide dip is the ability to vary the concentration of pesticide, and future research should certainly explore this (Morse and McNamara, in press). Cutting the concentration of pesticides in the dip would result in a reduction of the Field Use EIQ, potentially from moderate to low. With the seed dressing dusts, the dilution is not no easily achieved. While some recommendations for the use of seed dressing dust in the YMT suggest a mixing with wood ash as a low-cost input, the effectiveness of wood ash has been questioned.

Do the economic and environmental results reported here suggest that farmers should plant untreated setts? While these results provide evidence that farmers can make a profit from planting untreated setts in AYMT this is not to say that farmers should avoid using a pesticide dip. Given the challenges that may be involved in sourcing pesticide of the right price and quality then it may be an attractive option for farmers to plant untreated setts. But the use of sett treatments should not be judged in terms of an immediate economic return but also in terms of reducing pest and disease loads over the longer term. Nonetheless, there is an important question here about how long the treatment effect lasts for; can farmers use treated setts to produce 'mother' yam tubers which do not require further treatment for a season or perhaps longer? Coupled with the potential to reduce pesticide concentration in the dip then there is clearly much scope for future research.

\section{Conclusion}

The research reported here is the first designed to explore the economic and environmental impacts of sett treatment in the AYMT relative to the use of untreated setts. Sett treatment had a statistically significant and positive impact on agronomic variables, and this was reflected in a positive impact on revenue and gross margin. The use of untreated setts still generated a profit although it is better to treat yam setts to avoid re-infestation from the soil even if farmers may face challenges in obtaining pesticide of the required quality. Sett treatment also has a low-to-medium impact on the environment as assessed for the Field Use EIQ and there may be potential to reduce this further by varying the concentration of pesticides in the dip; a topic that does need more research.

Acknowledgements. The author acknowledges the help of Clement Agada and Gabriel Ameh in the Idah and Amoke areas, respectively along with Nora McNamara. The author would also like to thank Dr. Lava Kumar, Dr. Robert Asiedu, Dr. Beatrice Aighewi and Dr. Norbert Maroya, all of the International Institute of Tropical Agriculture (IITA), Nigeria. The author gratefully acknowledges the financial support for this work by the Bill \& Melinda Gates Foundation (BMGF) under the Yam Improvement for Income and Food Security in West Africa (YIIFSWA) grant awarded to the International Institute of Tropical Agriculture.

Finally, the author would like to thank the anonymous reviewers for their help in the improvement of this paper. 


\section{References}

Akinola A.A., Oke J.T.O., Adesiyan A.T. and Famuyini C.A (2019). Climate Change and Economic Efficiency of Yam Farmers in Ekiti State, Nigeria. Invited paper presented at the 6th African Conference of Agricultural Economists, September 23-26, 2019, Abuja, Nigeria

Emokaro C.O. and Law-Ogbomo K.E. (2008). The influence of minisett size on the profitability of yam production in Edo State, Nigeria. Research Journal of Agriculture and Biological Sciences 4, 672-675.

Eshenaur B., Grant J., Kovach J., Petzoldt C., Degni J. and Tette J. (undated). Environmental Impact Quotient: “A Method to Measure the Environmental Impact of Pesticides.” New York State Integrated Pest Management Program, Cornell Cooperative Extension, Cornell University. 1992-2019. Available at www.nysipm.cornell.edu/publications/EIQ

Ezeh N.O.A. (1991). Economics of seed yam production from minisetts in Umudike in Southeastern Nigeria: Implications for commercial growers. In Ofori F. and Hahn S.K. (eds.), Tropical Root Crops in a Developing Economy. Proceedings of the 9th Symposium of the International Society for Tropical Root Crops, 20-26th October, Accra Ghana, pp. 378-381.

Ezeh N.O.A. (1998). Economics of production and Post Harvest Technology. In Orkwuor G.C., Asiedu R. and Ekanayake I.J. (eds), Food yams: Advances in Research. Ibadan, Nigeria: International Institute of Tropical Agriculture, IITA, pp. 187-214.

George J. (1990). Effect of minisett size and nursery media on the sprouting of yams. Journal of Root Crops 16, 71-75.

Grant J.A. (undated). Calculator for Field Use EIQ (Environmental Impact Quotient). New York State Integrated Pest Management Program, Cornell Cooperative Extension, Cornell University. 2010-2019. Available at https://nysipm. cornell.edu/eiq/calculator-field-use-eiq/

Ibana S., Coyne D., Claudius-Cole A., McNamara N. and Morse S. (2012). Economic analysis of commercial seed yam production systems in the sub-humid ecologies of the River Niger. Journal of Crop Improvement 26, 22-38.

Igwilo N. and Okoli O.O. (1988). Evaluation of yam cultivars for seed yam production using the minisett technique. Field Crops Research 19, 81-89.

Iwueke C.C., Mbata E.N. and Okereke H.E. (1983). Rapid Multiplication of seed yam minisett technique. Advisory Bulletin, No.9. National Root Crop Research Institute, Umudike, Nigeria.

Kalu B.A., Norman J.C., Pal V.R. and Adedzwa D.K. (1989). Seed yam multiplication by the mini-sett technique in three yam species in a tropical guinea savanna location. Experimental Agriculture 25, 181-188.

Kovach J., Petzoldt C., Degni J. and Tette J. (1992). A method to measure the environmental impact of pesticides. New York's Food and Life Sciences Bulletin 139, 1-8.

Kusi F., Asante S.K., Adjebeng-Danquah J., Nutsugah S.K., Buah S.S.J., Owusu R.K., Wiredu A.N., Sugri I. and Zakaria M. (2013). Participatory integrated pest management strategy for improving shelf-life of yam (Dioscorea spp.). International Journal of Advance Agricultural Research 1, 124-132.

Levitan L., Merwina I. and Kovach J. (1995). Assessing the relative environmental impacts of agricultural pesticides: the quest for a holistic method. Agriculture, Ecosystems \& Environment 55, 153-168.

Mbah S.O. (2019). Determinants of yam production and profitability in Obubra Local Government Area of Cross-River State, Nigeria. International Journal of Agriculture and Rural Development 22, 4432-4440.

Mignouna D.B., Abdoulaye T., Alene A., Aighewi B., Pelemo O., Manyong V.M., Asiedu R. and Akoroda M. (2013). Economic analysis of seed yam production systems in Nigeria. Journal of Root Crops 39, 221-229.

Muhammetoglu A., Durmaz S. and Uslu B. (2010). Evaluation of the environmental Impact of Pesticides by Application of Three Risk Indicators. Environmental Forensics 11, 179-186.

Morse S. (2018). Analysis of yam minisett technique adoption in Nigeria. Journal of Crop Improvement 32, 511-531.

Morse S. and McNamara N. (2016). Fostering entrepreneurship to help provide a sustainable clean seed yam production system in flood prone areas of Idah, Kogi State, Nigeria. Agroecology and Sustainable Food Systems 40, $1085-1105$.

Morse S. and McNamara N. 2017. Impact of the Adapted Yam Minisett Technique on ware yam (Dioscorea rotundata) production under farmer-managed conditions in Nigeria. Experimental Agriculture 53, 131-143.

Morse S. and McNamara N. (2018a). Agronomic and economic performance of seed yam production using minisetts in the middle belt of Nigeria. Journal of Crop Improvement 32( 90-106.

Morse S. and McNamara N. (2018b). Factors influencing the agronomic performance of the adapted yam minisett technique in Nigeria - planting date and gender of the farmer. Experimental Agriculture 54, 1-15.

Morse S. and McNamara N. (in press). Pesticide residues in seed yams produced using the Adaptive Yam Minisett Technique. Journal of Crop Improvement.

Nwagbara E.C, Onuoha C.I. and Ezeji U.S. (2013). Comparative effects of apron plus and wood ash as minisett dusts for the sprouting of yam minisetts of Dioscorea rotundata Poir (white yam). International Science Research Journal 4 $56-60$.

Oduntan O. (2019). Gender differences in the technical efficiency and profitability of yam production among farmers in Ikole-Ekiti local government area, Ekiti State, Nigeria. The Pacific Journal of Science and Technology 20, 246-253.

Oguntade A.E., Thompson O.A. and Ige T. (2010). Economics of Seed Yam Production Using Minisett Technique in Oyo State, Nigeria. Field Actions Science Reports (Online) Vol. 4. Online since 21 January 2011. Available at http://factsreports. revues.org/659 (accessed 11 October 2012) 
Okeke E.C., Eneobong H.N., Uzuegbunam A.O., Ozioko A.O. and Kuhnlein H. (2008). Igbo traditional food system: documentation, uses and research needs. Pakistan Journal of Nutrition 7, 365-376.

Okoli O.O. (1986). Rapid propagation of yam by the minisett technique. In Cock J.K. (ed.), Global Workshop on root and Tuber Crops Propagation. Proceedings of Regional Workshop. Cali, Columbia: CIAT, pp. 119-122.

Onwueme I.C. and Charles W.B. (1994). Tropical root and tuber crops. Production, perspectives and future prospects. FAO Plant Production and Protection Paper 126. Food and Agriculture Organization of the United Nations, Rome.

Orkwor G.C. and Asadu R. (1998). Yam agronomy. In Orkwor G.C., Asadu R. and Ekanayake I.J. (eds), Food Yams: Advances in Research. Ibadan, Nigeria: International Institute of Tropical Agriculture, pp. 105-141.

Oruonye E.D. and Okrikata E. (2010). Sustainable use of plant protection products in Nigeria and challenges. Journal of Plant Breeding and Crop Science 2, 267-272.

Osiru D.S.O., Hahan S.K. and Lal R. (1987). Effect of mulching material and plant density on the growth, development and yield of white yam minisetts. In Terry E.R., Doku E.V., Arene O.B. and Mahungu N.M. (eds.), Root Crops and the African Food Crisis. Proceedings of the third triennial symposium of the International Society for Tropical Root Crops - African Branch, Owerri, Nigeria. Ottawaw, Canada: IDRC, pp. 43-47.

Otoo J.A. (1992). Substitutes for chemicals, sawdust and plastic mulch in improved seed yam production. In Akoroda M.O. and Arene O.B. (eds.), Promotion of root crop-based industries: An incentive for research and development. Proceedings of the fourth Triennial Symposium of the International Society for Tropical Root Crops - Africa Branch, Kinshasa, Zaire, pp. 281-284.

van der Werf H.M.G. (1996). Assessing the impact of pesticides on the environment. Agriculture, Ecosystems \& Environment 60, 81-96.

Cite this article: Morse S (2020). Environmental and economic impacts of pesticide treatment in the Yam Minisett Technique. Experimental Agriculture 56, 662-676. https://doi.org/10.1017/S0014479720000228 